\title{
Álcool, Cigarro e Hábitos Humanos
}

Nos anos 1900, principalmente no auge da indústria cinematográfica de Hollywood, o cigarro tinha um "Glamour" todo especial. Era "chique" fumar. Não havia herói, principalmente de guerras ou mocinho do "oeste americano" sem um cigarro aceso entre os dedos.

Não havia contra indicação conhecida e o apelo comercial era enorme. A indústria do tabaco cresceu de forma vertiginosa tornando-se economicamente e politicamente poderosa em muitos países, como a "terra de Marlboro".

Com a evolução do conhecimento médico, veio o homem descobrir os malefícios do fumo. Aos poucos, vozes foram se somando contra o tabagismo. Cálculos feitos começam a mostrar as perdas econômicas, além da saúde, em função do cigarro; como por exemplo, os gastos com tratamentos cada vez mais dispendiosos.

Apesar do poderio econômico, exemplificado no patrocínio do mais caro dos esportes, corridas de Formula I, a indústria do cigarro não teve como resistir e paulatinamente o cigarro em todo o mundo, vem sendo banido dos hábitos socialmente aceitos. Se dificilmente irá desaparecer, hoje se pode afirmar que ficará reduzido a um hábito marginal de poucos.

Dentre as explicações para essa mudança de comportamento em todo o planeta, pode estar o fato de em termos históricos, a convivência da sociedade com o tabaco ser relativamente recente (500 anos?) (descoberta das Américas?), sendo que o uso realmente intensivo do fumo não ter sido de muito mais de 200 anos, no último ou nos dois últimos séculos (19 e 20).

Talvez este fato, aliado à constatação de que há apenas malefícios, tenha ajudado na mudança de comportamento do homem, em que pese, ressalte-se, todo o poder econômico das industrias do tabaco que sempre subsidiaram esportes e lazer como corridas de carro e cinema.

Por outro lado, a convivência do homem com o álcool é milenar. Culturalmente, o álcool em suas variadas formas faz parte dos hábitos de vida de inúmeros povos, desde sempre.

Existe inclusive o que se poderá chamar de marca registrada de cada povo com sua bebida. Como exemplo têm-se: países europeus latinos-Itália, França, Portugal e Espanha com o vinho; Os Ingleses, Escoceses e Irlandeses com o whisky; o Alemão e a cerveja; a vodka e os Russos e Poloneses, o saque e o Japão, o rum e os Cubanos; a aguardente de cana e o Brasileiro; o champanhe e a França; o gim e a Holanda, em que pese ter sido difundido pelos ingleses; o conhaque e os Franceses e Espanhóis; a tequila e o México; enfim é enorme a lista dos povos que tem como uma de suas marcas registradas, um símbolo de sua cultura e habito, uma bebida alcoólica. 
Sem falar que para inúmeros rituais religiosos desde sempre a bebida alcoólica é parte integrante das cerimônias. O que ocorre nos quatro quadrantes do planeta.

Assim, enquanto o fumo historicamente é algo recente na história humana, o álcool faz parte da historia dos povos desde os primórdios da humanidade. Ressalte-se que não de um ou outro povo, de um ou outro continente, mas de todo o planeta.

Além desses aspectos, enquanto os danos à saúde advindos do fumo são muitos e fácies de serem identificados, sendo por assim dizer mais diretos, os danos à saúde causados pelo álcool, em sua maior parte, são danos indiretos mais complexos de serem percebidos pela população.

Acresça-se a isto, o fato de que em pequenas doses não haver dano, porque faz parte inclusive do hábito alimentar, por exemplo, dos europeus de origem latina (o vinho).

Enquanto o fumo sempre irá fazer mal, com o álcool isto pode não acontecer e efetivamente não acontece, passando a ser não mais uma questão dicotômica: consome, não consome, para tornar-se algo mais complexo, uma questão de dosagem.

Bem dizia, um grande sanitarista desse país, Prof.Dr. Walter Leser, que a diferença entre veneno e remédio está na dose utilizada.

Assim sendo, o combate ao álcool passa a ser muito mais difícil e delicado do que a todas as demais drogas sejam lícitas ou ilícitas.

Além da força econômica das indústrias de bebida, força esta inegável, aspectos sociais, culturais e religiosos, todos históricos, dificultam em muito a atuação dos profissionais de saúde neste campo.

O caminho deve ser outro, que não a proposta de eliminação, de proibição pura e simples como feito com o cigarro nos dias de hoje.

Duas vertentes devem ser atacadas de modo simultâneo.

Ensinar o uso com moderação, ou seja, redução de danos a ser feito à sociedade como um todo; o aspecto educacional nesse caso é de extrema importância; ensinar a beber com moderação, o que está começando a ser feito entre nós;

Em paralelo a isto, mensurar-se os diversos danos indiretos causados pelo álcool e importante, divulgando os resultados desses estudos, para que aos poucos possa a sociedade como um todo ir tomando uma maior consciência a respeito desse problema.

Nessa linha, estudo de hábitos, de uso em estudantes, os problemas ligados a suicídio, à gravidez, os problemas ligados ao atendimento bem como a capacitação de profissionais, além de todas as co-morbidades ligadas ao uso de álcool, tudo isto sem falar nas violências causadas pelo uso de álcool tais como acidentes de transporte e homicídios, são linhas de pesquisa cada vez mais utilizadas neste tema.

Só mesmo divulgando a infinidade de problemas relacionados ao uso de álcool bem como suas consequências conseguirá o homem 
diminuir os efeitos maléficos do uso abusivo do álcool, evitando assim as consequências maiores à saúde, individual e coletiva.

E é exatamente isto que a SMAD se propõe a fazer.

Moacyr Lobo da Costa Júnior

Professor Associado

Departamento de Enfermagem e Ciências Humanas

Escola de Enfermagem de Ribeirão Preto

Universidade de São Paulo

Centro Colaborador da OMS para o Desenvolvimento da Pesquisa em

Enfermagem

Brasil 